\title{
Development of Problem-based Blended Learning (PB2L) model to increase pre-service primary teacher's creative thinking skill
}

\author{
Wahyudi $^{1}$, St. Budi Waluya ${ }^{2}$, Hardi Suyitno ${ }^{3}$, Sutriyono ${ }^{4}$, Indri Anugraheni ${ }^{5}$ \\ ${ }^{1,4,5}$ Faculty of Teacher Training and Education, Universitas Kristen Satya Wacana, Indonesia \\ ${ }^{2,3}$ Mathematics Education, Universitas Negeri Semarang, Indonesia
}

\section{Article Info}

\section{Article history:}

Received Mar 8, 2019

Revised May 16, 2019

Accepted Jun 1, 2019

\section{Keywords:}

Creative thinking skills

Pre-service primary teacher

Problem-based Blended

Learning (PB2L)

\begin{abstract}
Problem-based learning is generally done with face-to-face interaction. This learning process, however, has not provided a lot of time for learners to find limitless and timeless information and learning resources. It still depends on the teacher as a source of information. Students are very dependent on the presence of lecturers during face-to-face interaction. This research aims to develop a Problem-based Blended Learning (PB2L) model to support student to improve their creative thinking skills. The method used in this research was R\&D with ASSURE development model. Product validation was done through an expert's assessment by using the expert's validation sheet. The practicality of the product is tested with limited trials with college lecturers and some students with questionnaires and interviews. Product effectiveness was seen by implementing limited development testing to a particular class with a one group pretest-posttest design and the result was analyzed by using a Paired-Samples T-Test. The result of this research is a Problem-based Blended Learning (PB2L) valid, practical and effectively improves students' creative thinking abilities. The effectiveness of the learning model was also proven on the basis of Paired-Samples T-Test of students' pretest and posttest with sig. (2-tailed) 0.000 . This learning gives students the opportunity to think systematically by beginning by criticizing the interesting contextual problems and ending with meaningful reflection with adequate learning resources both in face-to-face and online interaction.
\end{abstract}

Copyright ( 2019 Institute of Advanced Engineering and Science. All rights reserved.

\section{Corresponding Author:}

Wahyudi,

Faculty of Teacher Training and Education,

Universitas Kristen Satya Wacana,

J1. Diponegoro 52-60 Salatiga, 50711, Indonesia.

Email: yudhi@staff.uksw.edu

\section{INTRODUCTION}

Creative is an important and competency for everyone to possess. One of the goals of Indonesian education is to make human beings creative [1]. Creative is also one of the main components of 21 st century education [2] and is the highest level of competency in the latest Bloom taxonomy [3]. Therefore, the content curriculum emphasizes the development of creative thinking skills for students $[4,5]$. The ability to think creatively will lead to the acquisition of new insights, new approaches, new perspectives, or new ways of understanding a problem.

The creativity of students becomes something that needs to be developed in education. This is in line with the results of the Dyers [6] study which states that $\frac{2}{3}$ from the ability of one's creativity to be obtained through education, $\frac{1}{3}$ the rest comes from genetics. Conversely for intelligence abilities that apply $\frac{1}{3}$ 
intelligence ability is obtained from education, $\frac{2}{3}$ the rest is genetic. This means that we cannot do much to improve one's intelligence but we have many opportunities to improve their creativity. Creativity is included in the field of mathematics, especially the ability to think creatively. Thus the ability to think creatively in the field of mathematics needs to be developed so that students have high creativity in solving mathematical problems.

The real problem in learning, not all mathematics learning in schools provides opportunities for students to develop creative thinking skills including in the field of mathematics. Learning is more oriented to the amount of material given and the acquisition of academic values that focus on cognitive abilities. Learning is only in the context of achieving the test score target and giving students less experience in thinking, reasoning and solving problems [7]. This condition also occurs in learning mathematics in higher education including prospective teacher students. Mathematics learning has not provided an opportunity for students to improve reasoning skills and think creatively in solving problems [8,9]. This situation finally affected the learning pattern when they became teachers and taught in schools. Mathematics is often an unattractive information so it is forgotten, does not last long in the student brain.

For this reason, packaging of the appropriate learning model is needed. Learning mathematics must match the context of the reality of student life, thus mathematics is easy to remember, imagine, represented, manipulated and assembled in a good map of cognitive maps [10]. This is in accordance with the paradigm of learning mathematics today, where mathematics is close to humans, mathematics is part of human culture $[7,11,12]$ and is part of social reality $[11,13]$. One model that can be applied is problem based learning. Problem based learning provides opportunities for students to get used to managing problems and thinking of many alternative solutions to problems properly and correctly. To get a solution to diverse and creative problems, a large and extensive vehicle of information is needed regarding how to solve problems both from the fluency aspect, flexibility, novelty, and elaboration with the help of technology and computational modeling that makes it easy for them to learn abstract things. Learning models packaging like this requires special skills for a teacher. Material (content) is not enough, or the ability to design learning (pedagogical) wouldn't do but must be able to combine the two. Not only does it require special abilities, namely the use of technology in learning (technological). By combining these three capabilities, learning in the classroom will be more interesting, efficient and meaningful for students and packaged in problem-based face-to-face and online learning (blended learning) with computational modeling. This learning will provide opportunities to students to search for information related to problem-solving provided with new and creative solutions in face-to-face activities or online. This learning which later would be named Problem Based Blended Learning (PB2L). With this learning process, it will opportunities for students to obtain many sources and learn a lot from other people thus it would give them inspiration in solving problems.

\section{RESEARCH METHOD}

\subsection{Development method}

The product generated from this research and development is blended learning based on problem which later could support the improvement of thinking creatively by the students in mathematics. The method used includes descriptive and evaluative methods. Descriptive method is used to collect the existing condition in the field. Evaluative method is used to evaluate the feasibility of blended learning based on problem model which is realized in the form of activities and learning guidelines. Through the product and process of trial, it is expected that it could obtain inputs about advantages and deficiency of the product developed. The idea of development for blended learning based on problem model is developmed based on Borg and Gall model [14]. Based on the purpose and design of learning which not only limited to face-toface stage then the development stage is done with the stage of ASSURE stage. The ASSURE development stages is done in 6 stages namely 1) analyze learners, 2) state objectives, 3) select strategy, technology, media, and materials, 4) utilize media and materials, 5) require learner participation, 6) evaluated and revise [15]. It is clearly seen in Figure 1. 


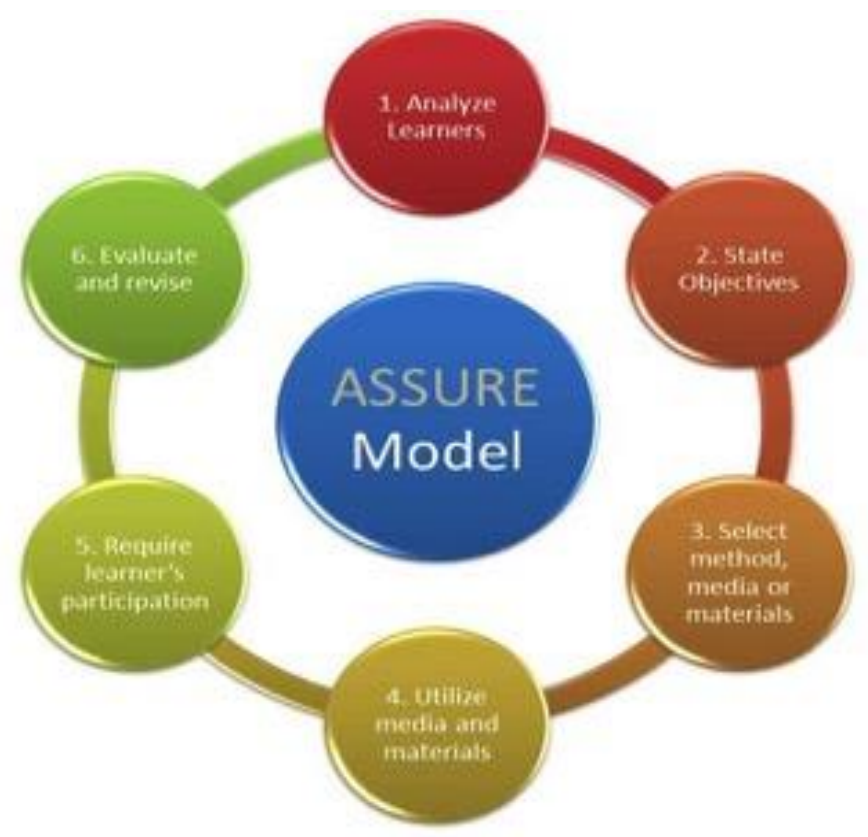

Figure 1. Development model of ASSURE

\subsection{Population and research sample}

The population in this study was the PGSD FKIP SWCU class of 2017 students. The samples used were 2 classes, namely class A and B. The reason for choosing the population and sample was when they were taking a course in solving mathematical problems. This is precisely because the competencies to be improved are the ability to think creatively in solving mathematical problems.

\subsection{Data collection techniques and instruments}

Data collection techniques used are expert tests, questionnaires, observations and tests. The expert test is used to see the expert's perception of the feasibility of the product (valid) produced, the questionnaire is used to see the response of students and teacher perceptions in implementing the model (practicality), observation is used to see the implementation of the model syntax developed, and the test is used to see the impact of learning done namely the ability to think creatively by students (model effectiveness). The instruments used in this study were expert validation sheets, student and teacher response questionnaires, learning observation sheets, and test questions.

\subsection{Data analysis technique}

Data from expert assessment test results (product validation) were analyzed using percentage descriptive techniques and categorically to describe the feasibility of the model. Initially the score of the measurement results using a closed questionnaire is summed and averaged between the results of the expert score 1 with expert 2 . Then the score is in percentage using the formula:

Actual Score

PN = -------------- x 100\%

Note

Ideal Score

$\mathrm{PN}$

Actual Score

Percentage Number

Ideal Score

Scores given by expert validators

: Maximum score between the number of items and the maximum score of each item.

Based on the percentage category above, the Problem Based Blended Learning (PB2L) model can be said to be feasible to be tested if the minimum percentage rate reaches a high category $(\geq 61 \%)$. The practicality test is done by looking at the results of the response of colleagues and students when testing the limited application of the model. The effectiveness test was done by comparative analysis, which compares 
the results of the mathematics learning design before and after the application of the model for one class with one group pretest-posttest design using creativity criteria which include aspects of flexibility, novelty and elaboration. Based on the results of these three criteria then the final score is determined. Final scores before and after the application of the model were compared with the Paired-Samples $\mathrm{T}$ Test with the help of SPSS 23.

\section{RESULTS AND ANALYSIS}

\subsection{Model development results}

The development of models using the ASSURE model is carried out in 6 stages of development; a) analyze learners; b) state objectives; c) select strategy, technology, media, and materials; d) utilize media and materials; e) require learner participation; f) evaluated and revise [15]. The results of each stage of development can be explained below.

\section{a. Analyze learners}

Subject characteristics are seen from the ability to think creatively in solving mathematical problems and the ability to use IT and the internet for learning resources. This result is the result of a preliminary study that will be the basis for developing the model. The results obtained are shown in Table 1, Table 2 and Table 3.

Table 1. The results of the initial measurement of students' creative thinking abilities

\begin{tabular}{clcc}
\hline Interval & Category & Frequency & Percentage \\
\hline $82-100$ & Very high & 0 & 0 \\
$63-81$ & High & 5 & 18 \\
$44-62$ & Moderate & 10 & 36 \\
$25-43$ & Low & 12 & 46 \\
Total & & 27 & 100 \\
\hline
\end{tabular}

Table 2. Categories of creative thinking abilities according to categories

\begin{tabular}{clll}
\hline No & Creative Thinking Ability $(\mathrm{KBK})$ & Average & Category \\
\hline 1 & Fluency & 75 & High \\
2 & Flexibility & 41 & Low \\
3 & Novelty & 31 & Low \\
4 & Elaboration & 50 & Moderate \\
\hline
\end{tabular}

Table 3 . The ability of students to use IT and the internet as a learning resource

\begin{tabular}{cccccc}
\hline Competence Category & SB & B & KB & TB & Total \\
\hline Ability to use IT and internet & 10 & 15 & 2 & 0 & 27 \\
\hline$*$ SB ( Very Good), B (Good), KB (Low), TB (Not Good) & &
\end{tabular}

Based on the data in Table 2 and Table 3, obtained information that most students (82\%) have creative thinking skills in the medium and low categories. Judging from the 4 indicators of creative thinking only the fluency indicator with a high category. Only the ability to use IT and internet in the category of very good and good, namely $92 \%$ (25 students).

Based on the data obtained then classical interviews were conducted to get the initial picture that the subject was getting was not like mathematics. They took majors that allowed them not to meet with much mathematics such as social studies for high school and MA and to take vocational school. Thus the low ability to think creatively is not solely because of their inability to apply the four aspects of creative thinking but is caused by their lack of love for mathematics thus that feeling influences their creative thinking ability.

\section{b. State objectives}

After conducting an initial capability analysis, the next step is to determine competencies, make a description and formulate the objectives of the lecture. The following is a description and example of competencies and learning objectives that will be achieved in the Mathematics Problem Solving Strategy course as shown in Table 4. 
Table 4. Basic competence and description of strategies for solving mathematical problems subject

\begin{tabular}{|c|c|}
\hline Subject Basic Competence & Subject Description \\
\hline $\begin{array}{l}\text { Students are able to understand the concept of problems and understand } \\
\text { problems in mathematics } \\
\text { Students are able to distinguish between routine and non-routine problems } \\
\text { in mathematics } \\
\text { Students are able to know the difference in problem solving strategies } \\
\text { according to Polya and Reys } \\
\text { Students are able to solve problems related to numbers } \\
\text { Students are able to solve problems related to arithmetic sequence and series } \\
\text { Students are able to solve related problems related to geometry problems } \\
\text { Students are able to solve related problems related to geometry problems } \\
\text { Students are able to solve related problems related to geometry problems in } \\
\text { building space } \\
\text { Students are able to solve related problems related to systems of linear } \\
\text { equations }\end{array}$ & $\begin{array}{l}\text { This course aims to strengthen students' ability } \\
\text { to understand and solve mathematical problems } \\
\text { so that students have high creativity in } \\
\text { producing many problem solving with new and } \\
\text { diverse categories. This course discusses the } \\
\text { basic concepts of mathematical problems and } \\
\text { problem solving in elementary school, routine } \\
\text { and non-routine problems (open ended), } \\
\text { problem solving strategies according to Polya } \\
\text { and Reys, solving mathematical problems with } \\
\text { Polya and Reys strategies for material numbers, } \\
\text { arithmetic sequence and series, geometry of } \\
\text { building flat and building space, and problem } \\
\text { solving related to systems of linear equations. }\end{array}$ \\
\hline
\end{tabular}

Based on the formulation of competency and description of the course and the data on the initial ability of students, then the learning objectives were formulated for each meeting both face-to-face and online lectures. Details can be explained in the following Table 5.

Table 5. Examples of formulation of learning objectives of the constitutional court strategies for solving mathematical problems

\begin{tabular}{|c|c|}
\hline \multicolumn{2}{|c|}{ Examples of formulation of face-to-face learning objectives } \\
\hline Meeting & Formulation of Learning Objectives \\
\hline 1 & $\begin{array}{l}\text { Given the opportunity to examine the material and discuss with lecturers about several events related to the problem of } \\
\text { human life, students were able to formulate their own language the meaning of problems and problems in mathematics }\end{array}$ \\
\hline 6 & $\begin{array}{l}\text { Given the opportunity to observe several patterns of numbers in group work activities, students were able to solve } \\
\text { problems related to arithmetic sequences and series with collections and correct }\end{array}$ \\
\hline 7 & $\begin{array}{l}\text { Given the opportunity for group work with the help of pictures and videos as a source of problems, students were able } \\
\text { to solve problems related to geometry problems to construct flat sides with a flat and correct side. }\end{array}$ \\
\hline \multicolumn{2}{|c|}{ Examples of formulas for online learning goals } \\
\hline Meeting & Formulation of Learning Objectives \\
\hline 1 & $\begin{array}{l}\text { Given the opportunity to watch videos about the pattern of odd numbers, students were able to find the equation to } \\
\text { determine the term n (Un) and the number of nth (Sn) terms carefully and correctly. }\end{array}$ \\
\hline 4 & $\begin{array}{l}\text { Given the opportunity for group work with the help of pictures and videos as a source of problems, students were } \\
\text { able to solve related problems related to geometry problems to build space with collections and correct. }\end{array}$ \\
\hline 5 & $\begin{array}{l}\text { Given the opportunity to observe videos about eating events in restaurants, students were able to solve related } \\
\text { problems related to systems of linear equations with collusion and correctness. }\end{array}$ \\
\hline
\end{tabular}

\section{c. Select method, media, and materials}

The third step in this development method was to establish methods, media, and teaching materials that will be used both face-to-face and online learning. The results obtained were divided into two categories of methods, media and teaching materials provided, namely for face to face and online. For face-to-face methods used were discussion and group work with a problem based learning model and power point media which contains motivation and activities that must be done to solve the mathematical problems given. For online lectures activities were packaged in the form of problem solving with problem based learning with activities and instructions provided in the online class, F-learning (flearn.uksw.edu).

\section{d. Utilize media and materials}

The designs that have been made in step 3 were then compiled in both face-to-face and online learning plans. The tools needed include the Lecture Event Unit (SAP), Student Worksheets (LKM), Media (power point, video, audio, images, and material in online classes). Devices that have been compiled, tested by experts first include learning experts, media experts, and experts in teaching materials / materials to obtain product validity. In detail the results of product validation are presented in Table 6.

Table 6. Expert assessment results for PB2L model

\begin{tabular}{llcccccc}
\hline \multirow{2}{*}{ No } & \multirow{2}{*}{ Indicator } & Ideal & \multicolumn{2}{c}{ Actual Score } & \multirow{2}{*}{ Average } & PN (\%) & \multirow{2}{*}{ Category } \\
\hline 1 & Design of learning activities & Score & Expert 1 & Expert 2 & & $51 \%$ & Very high \\
2 & Instructional Media & 30 & 24 & 22 & 23 & $73 \%$ & High \\
3 & Teaching materials and learning resources & 35 & 26 & 24 & 25 & $71 \%$ & High \\
4 & Learning evaluation instruments & 55 & 41 & 40 & 40.5 & $74 \%$ & High \\
\hline
\end{tabular}

J. Edu. \& Learn. Vol. 13, No. 3, August 2019 : 324 - 334 
Based on the feasibility criteria of the model developed the results are very high and high (Percentage Number $(\mathrm{PN}) \geq 61 \%$ ) thus the model is feasible to use. The next step was to implement the model on a limited scale to see the practicality of the model. Limited testing was carried out for one lecturer with 8 students. The results obtained are shown in Table 7 and Table 8 .

Table 7. Peer assessment (model practical test)

\begin{tabular}{clccc}
\hline No & \multicolumn{1}{c}{ Indicator } & Ideal Score & Actual Score & AP $(\%)$ \\
\hline 1 & Design of learning activities & 60 & 52 & $87 \%$ \\
2 & Instructional Media & 55 & 43 & $78 \%$ \\
3 & Teaching materials and learning resources & 30 & 24 & $80 \%$ \\
4 & Learning evaluation instruments & 35 & 28 & $80 \%$ \\
\hline
\end{tabular}

Based on the results of the assessment and implementation of the model by peers the value of the learning design (face to face and online), the media and teaching materials developed in the category of very high and high (AP value $\geq 61 \%$ ) thus practical models are used. Based on the data in Table 8 , it can be seen that student assessment for 4 aspects, namely face-to-face and online learning, media and teaching materials obtained $87.5 \%$ with very good and good categories thus practical and feasible models were used in further learning in a broad test of one class.

Table 8. Response of limited test students (practicality test models)

\begin{tabular}{|c|c|c|c|c|c|c|c|c|c|c|c|}
\hline \multirow{2}{*}{ No } & \multirow{2}{*}{ Aspects responded } & \multicolumn{10}{|c|}{ Students' Response } \\
\hline & & TB & $\%$ & $\mathrm{~TB}$ & $\%$ & $\mathrm{CB}$ & $\%$ & $\mathrm{~B}$ & $\%$ & SB & $\%$ \\
\hline 1 & Design of learning activities & 0 & 0 & 0 & 0 & 1 & 12,5 & 4 & 50 & 3 & 37,5 \\
\hline 2 & Instructional Media & 0 & 0 & 0 & 0 & 2 & 25 & 4 & 50 & 2 & 25 \\
\hline 3 & Teaching materials and learning resources & 0 & 0 & 0 & 0 & 1 & 12,5 & 3 & 37,5 & 4 & 50 \\
\hline 4 & Learning evaluation instruments & 0 & 0 & 0 & 0 & 1 & 12,5 & 5 & 62,5 & 2 & 25 \\
\hline
\end{tabular}

\section{e. Require learner participation}

The next step was to involve students in one class in learning. Students must be actively involved in learning to see the effectiveness of the model developed and the achievement of learning objectives. Because the design used was Problem Based Blended Learning (PB2L), students are required to be independent. The learning process was carried out according to a predetermined design both face to face and online. Learning was done in 15 meetings. Examples of displaying online classes can be seen in Figure 2.

\section{WELCOME TO THE COURSE ONLINE FACILITIES \\ Strategi Pemecahan Masalah Matematik Lecturer: Wahyudi, S.Pd., M.Pd}

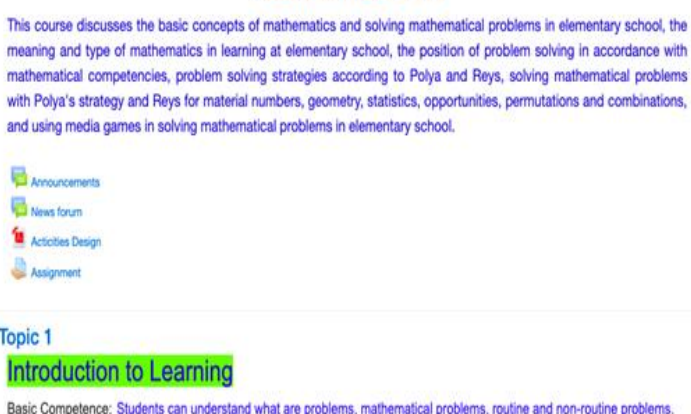

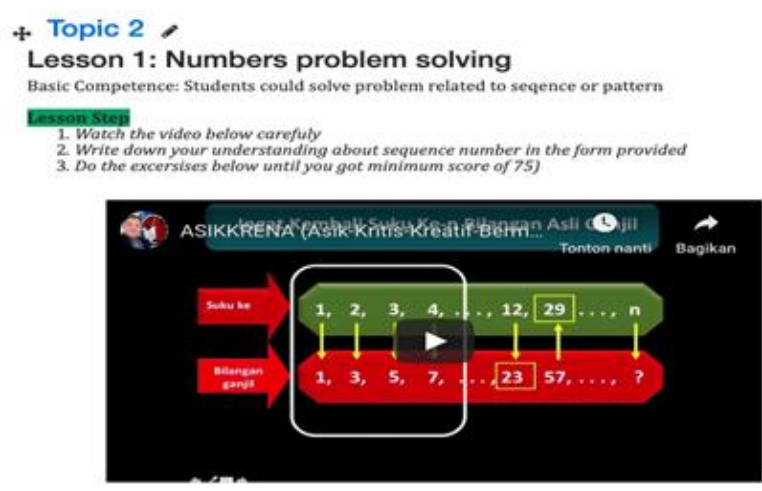

Please do the following self-task сиск ғонм

Figure 2. Display of online classes

In addition to attending online lectures and doing assignments and making products for each task, students were also required to do formative tests that have been provided online. This test was intended to see the progress of independent learning from each student so as to achieve mastery learning. To provide an opportunity to produce several problem solving and creative products, students were also required to make a creative product related to solving mathematical problems given. It was intended that students not only imitate what the lecturers taught but have their own ideas in the form of problem-solving work made in 
creative products. Here is an online display for creative products in the form of solving mathematical problems as shown in Figure 3.
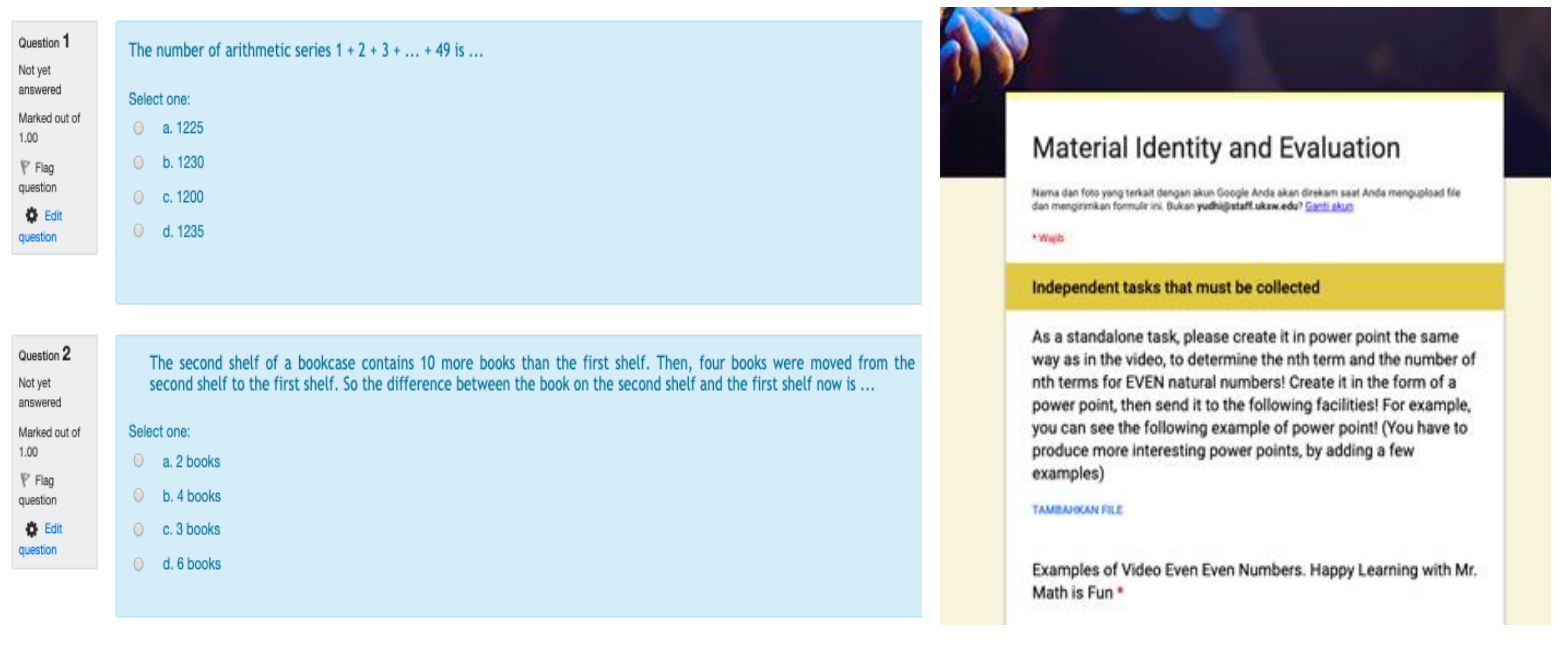

Figure 3. Display of formative tests and assignments for creative products solving mathematical problems

To see the effectiveness of the model, a trial was conducted for 1 class according to the sequence of activities and principles of Problem Based Blended Learning (PB2L). Students who were selected as samples will be given a pretest and posttest to see the ability to think creatively before and after the Problem Based Blended Learning (PB2L) model was applied. The results of the pretest and posttest of students' creative thinking abilities can be seen in Table 9, Table 10 and Table 11.

Table 9. Descriptions of results of the pretest and postes students' creative thinking ability

\begin{tabular}{lcc}
\hline Category & Pre Test & Post Test \\
\hline Mean & 60.52 & 75.96 \\
Std. Deviation & 9.60 & 6.36 \\
Minimum & 45.00 & 68.00 \\
Maximum & 80.00 & 90.00 \\
\hline
\end{tabular}

Based on the data in Table 10, the mean of the pretest and posttest results is 60.52 and 75.96 with the standard deviation resulting in 9.60 and post 6.36 pretest with the standard error pretest 1.85 and posttest 1.22. These results indicate that the ability to think creatively in the posttest results is closer to the mean value than the pretest. Thus the post-test value is smaller than the pretest results seen from the average value (mean).

Table 10. The results of the categories and the level of pretest and post-ability of students' creative thinking skills

\begin{tabular}{cccccc}
\hline \multirow{2}{*}{ Interval } & \multirow{2}{*}{ Category } & Total & Pretest & \multicolumn{2}{c}{ Posttest } \\
& & Percentage & Total & Percentage \\
\hline $82-100$ & Very high & 0 & 0 & 11 & 40.74 \\
$63-81$ & High & 2 & 7.41 & 16 & 59.26 \\
$44-62$ & Moderate & 19 & 70.37 & 0 & 0 \\
$25-43$ & Low & 6 & 22.22 & 0 & 0 \\
Total & & 27 & 100 & 27 & 100 \\
Average & & \multicolumn{2}{c}{60.52} & & \multicolumn{2}{c}{75.96} \\
\hline
\end{tabular}

The pretest data shows that the initial ability of students before participating in learning with the Problem Based Blended Learning (PB2L) model is in the medium and low category, which is $92.59 \%$ (25 people out of 27 people). Only $7.41 \%$ ( 2 people) are in the creative category. These results indicate that students' creative thinking skills still need to be improved. 
After participating in learning with Problem Based Blended Learning (PB2L), there was an increase in the number of students who had creative and moderate categories. Creative category improvement from $7.41 \%$ ( 2 people) to $40.74 \%$ (11 people). The number of students with moderate and weak categories decreased from $92.59 \%$ ( 25 people) which decreased to $59.26 \%$ (16 people). This shows an increase in the ability to think creatively before and after participating in learning with Problem Based Blended Learning (PB2L).

These results are also supported by observations when they were working on test questions. Students worked on the problem independently with the stages of solving problems that have been directed and produced several solutions even though they were not in accordance with the aspect of creative thinking can be carried out optimally. The description of the results of the observations can be seen from Table 11 .

Table 11. Observation results of student activities when working on the test

\begin{tabular}{lccc}
\hline \multicolumn{1}{c}{ Aspect of BKM } & \multicolumn{3}{c}{ Question Number } \\
\hline Fluency & 20 & 2 & 3 \\
Flexibility & 18 & 20 & 22 \\
Novelty & 12 & 16 & 15 \\
Elaboration & 11 & 11 & 11 \\
\hline
\end{tabular}

To further see the impact of applying Problem Based Blended Learning (PB2L) in learning, it is necessary to test the effectiveness of the model by using statistical tests paired $\mathrm{T}$ tests. This was chosen because the research design used quasi experiment with one group pre test post test design. There is a weakness of this design because it only uses one class. The following are the results of paired $\mathrm{T}$ tests which begin with the data normality test as seen in the data in Table 12.

$\underline{\text { Table } 12 \text {. Results of normality test of creative thinking abilities and posttest }}$

\begin{tabular}{lcccccc}
\hline & \multicolumn{3}{c}{ Kolmogorov-Smirnova } & \multicolumn{3}{c}{ Shapiro-Wilk } \\
& Statistic & df & Sig. & Statistic & df & Sig. \\
\hline Pre Test & .145 & 27 & .150 & .930 & 27 & .068 \\
Post Test & .153 & 27 & .107 & .932 & 27 & .077 \\
\hline a Lilliefors Significance Correction & & &
\end{tabular}

The number of students taken as a sample was only 27 people so the results of normality taken were the results of normality with Shapiro-Wilk. As per the data in Table 14 the value of Sig is obtained. The pretest and posttest were 0.068 and 0.077 both were greater than 0.05 so the two data were normally distributed. This result is a condition for the following steps, namely Paired Samples T Test. The results obtained can be seen in Table 13 .

Table 13. Paired samples T test results on creative thinking ability

\begin{tabular}{lcccc}
\hline \multicolumn{5}{c}{ Paired Samples Correlations } \\
& $\mathrm{N}$ & Correlation & Sig. \\
\hline Pair 1 & Pre Test \& Pos Test & 27 & .777 & .000 \\
\hline
\end{tabular}

Table 14. Paired samples T test results on creative thinking ability

\begin{tabular}{|c|c|c|c|c|c|c|c|c|}
\hline \multicolumn{4}{|c|}{ Paired Differences } & & & & & \\
\hline & \multirow[t]{2}{*}{ Mean } & \multirow[t]{2}{*}{ Std. Deviation } & \multirow[t]{2}{*}{ Std. Error Mean } & \multicolumn{2}{|c|}{$\begin{array}{l}\text { 95\% Confidence Interval } \\
\text { of the Difference }\end{array}$} & \multirow[t]{2}{*}{$\mathrm{t}$} & \multirow[t]{2}{*}{ df } & \multirow[t]{2}{*}{ Sig. (2-tailed) } \\
\hline & & & & Lower & Upper & & & \\
\hline Pair 1 Pre Test - Pos Test & -15.44 & 6.14 & 1.182 & -17.87 & -13.01 & -13.06 & 26 & .000 \\
\hline
\end{tabular}

Based on the data in Table 10 and Table 11, it is found that the sig value. $0,000<0.05$ and $t$ count (13.06) $>t$ table (2.05), it was found that there were significant differences between the results of the pretest and posttest. Where the posttest results are better than the pretest results. Thus, it can be concluded that the application of Problem Based Blended Learning (PB2L) is effective in improving students' creative thinking skills in solving mathematical problems. 


\section{f. Evaluated and revise}

Based on the results of expert assessment and implementation of learning there are several online facilities that must be improved. In online learning there needs to be detailed instructions for each online activity to reduce the number of questions when students learn independently. There needs to be a real video in mathematics learning related to mathematical problem solving so that students can learn independently to achieve mastery learning.

In accordance with the description of the 6 steps of development that have been carried out, the Problem Based Blended Learning (PB2L) model is declared valid, practical and effective. Thus it can be said that the Problem Based Blended Learning (PB2L) model is effective to improve students' creative thinking skills in solving mathematical problems. This can be seen from the Paired samples test with an average pretest of 66.45 and posttest 83.06 with sig. (2-tailed) 0,000 meaning that there are differences before and after the model is applied. Problem Based Blended Learning (PB2L).

This happens because the learning situation is prepared and implemented in accordance with the context of student life, and is packaged in fun activities. This is in accordance with the paradigm of learning mathematics today, where mathematics is close to humans, mathematics is part of human culture $[7,11,12]$ and is part of social reality $[11,13]$. This is also in accordance with the research of Wahyudi, Waluya, \& Rochmad [16], learning with scaffolding in an interesting and correct way and using contextual problems can provide motivation for students to want to learn mathematics and be able to solve mathematical problems. The results of the interview show that motivating with interesting, contextual things, easy to imagine, not always in the form of formulas and numbers, makes them interested and willing to learn mathematics.

In addition, students also get direct experience through contextual events, students also get experience in online learning that has been prepared. Learning can be accessed at http://flearn.uksw.edu in the course of solving mathematical problems. This condition provides opportunities for students to have a vehicle that is sufficient as a learning resource that can be accessed anytime and anywhere according to their preferences. In addition to that, this model allows students to see creative and unusual problem solving methods with interesting approaches so as to inspire them to produce problem solving in new ways. This is in accordance with the principle of creativity arising from opportunities. There are $3 \mathrm{~N}$ activities (Niteni, Nerokke, Nambahi) taught by Ki Hajar Dewentara. This concept makes the idea that creativity will emerge if students are given the opportunity. Creativity that appears is still at the level that must look at the example first. The results of the interviews support this statement, students at the initial level tend to imitate thus the idea is to think of other creative works. This is in accordance with the opinion of Hsieh [17] that the teaching style of a teacher can influence the learning reflection of his students (in this case students). So if you want to produce creative students, lecturers must be creative first in designing and implementing learning. This is in line with the opinion of Morais \& Azevedo [18], good teachers must be creative so that they can be an example for their students to create further. In addition to something creative that can be exemplified, teacher creativity is also one of the best habits of teaching creative thinking and always developing, and developing $[19,20]$. The success of this model increases the ability to solve mathematical problems, also because of the obligation of students to produce creative work that is the result of their creative thinking in solving problems. Students are given extensive opportunities for discussion with their team, looking for information and data that is sufficient and not limited to time and place and the role of the lecturer directly. This is in accordance with the opinion of Boelens et al., [21] learning must be able to stimulate student interaction, facilitate their learning process, and encourage an affective learning situation. Each of their learning activities has been designed and prepared from the start and explained to students the target products that must be produced and how they can meet these targets. To that while maintaining their presence in the team they will try to meet the predetermined targets.

Student creativity in solving mathematical problems is also supported by a learning environment that fosters creativity from among students themselves [22, 23]. There is an opportunity for each group to present the results in a face-to-face class, thus encouraging other groups to produce better works. This very positive learning environment triggered students with their teams to continue to improve their creative work. Positive learning environments are also provided by lecturers in the form of learning simulations by lecturers using animation media, images and even video realities of life that are close to students thus they are easy to understand. This is consistent with the results of research by [24, 25] that a positive learning environment will motivate students and be creative to produce something useful.

\section{CONCLUSION}

Based on the results of data analysis and discussion, it can be concluded that Problem based Blended Learning (PB2L) valid, practical and effectively improves students' problem solving in creative thinking abilities. This happens because learning gives students the opportunity to think systematically by beginning 
by criticizing the interesting contextual problems and ending with meaningful reflection with adequate learning resources both when face-to-face and online. Creative students because lecturers give them the opportunity to do something creative in creative activities.

Based on the results of research has been conducted on the research results, the suggestions of the results of this study are lecturers are suggested to give their students a great opportunity to develop their creativity in solving mathematical problems. Gives students the opportunity to think systematically by beginning by criticising the interesting contextual problems and ending with meaningful reflection with adequate learning resources both when face-to-face and online.

\section{ACKNOWLEDGEMENTS}

Huge gratitude to the Satya Wacana Christian University especially the Assistant Chancellor V Office for providing financial assistance through the 2017-2018 fiscal year competition grant.

\section{REFERENCES}

[1] Constitution No. 20 Tahun 2003 concerning the National Education System (in Bahasa).

[2] Mann, E.L., Mathematical creativity and school mathematics: Indicators of mathematical creativity in middle school students, Connecticut: University of Connecticut, 2005.

[3] Stanny, C.J., "Reevaluating Bloom's Taxonomy: What measurable verbs can and cannot say about student learning," Education Sciences, vol. 6, no. 37, 2016.

[4] Vale, I. and Barbosa, A., "Mathematics creativity in elementary teacher training," Journal of the European Teacher Education Network, vol. 10, pp. 101-109, 2015.

[5] Sternberg. R. J., "The nature of creativity," Creativity Research Journal, vol. 18, no. 1, pp. 87-98, 2006.

[6] Dyers, J.H. et al., Innovators DNA: Mastering the five skills of disruptive innovators. Harvard Business Review, 2011.

[7] Rachmawati, I., "Exploration of Sidoarjo society etnomathematics (in Bahasa)," Ejournal Unnes, vol 1, no 1, 2012.

[8] Suarma, D. M., and Kusumah, Y. S., "Interaction between literacy factors and learning against the mathematical deductive reasoning ability of prospective elementary school teacher students and their performance," EDUHUMANIORA: Jurnal Pendidikan Dasar, vol. 4, no. 1, 2016.

[9] Wahyudi, Waluya, B., and Rochmad. "Scaffolding based on learning style as an effort to increase mathematical creative thinking skill," The International Journal of Research in Teacher Education, vol. 9, no. 1, pp. 34-44, 2018.

[10] Wahyudi and Waluya, B., "the importance of cognitive psychology in mathematics learning and students' creativity," Proceeding International Conference on Mathematics, Science, and Education (ICoMSE), Malang State University. Malang, 2017.

[11] Hersh, Reuben, What is mathematics, really? London: Jonathan Cape, 1997.

[12] Siswono, T. Y. E., Humanistic mathematics learning that develops student creativity (in Bahasa). Yogyakarta: Universitas Sanata Dharma, pp. 1-16, 2007.

[13] Zevenbergen, R., Dole, S., and Wright, R., Teaching mathematics in primary schols. Autralia: ALLEN \& UNWIN. 2011.

[14] Gall, M.D., Gall, J.P., and Borg, W.R., Educational research. An instroduction, 8th edit., New York: Pearson. 2007.

[15] Smaldino, S.E,Russel, J.D. Heinich, R., and Molenda, M., Intructional technology and media for learning. New Jersey: Pearson Merril Prentice Hall Inc, 2005.

[16] Wahyudi, Waluya, B., Rochmad, and Suyitno, H., "Mathematical creative thinking ability and scaffolding process according with learning styles for pre-service teachers," Anatolian Journal of Instruction, vol. 3, no. 1, pp. 39-50, 2018.

[17] Hsieh, S.W., et.al., "Effects of teaching and learning styles on students' reflection levels for ubiquitous learning," Computers \& Education, vol. 57, no. 1, pp. 1194-1201, August 2011.

[18] Morais, Maria Fatima, and Azevedo Ivete, "What is a creative tecaher and what is a creative pupil? Perceptions of teachers," Procedia Social and Behavioral Sciences, vol. 12, pp. 330-339, 2011.

[19] Henriksen, Danah, "The seven transdisciplinary habits of minds of creative teachers: An exploratory studi of award winning teachers," Teaching Skills and Creativity, vol. 22, pp. 212-232, December 2016.

[20] Wahyudi, W., Suyitno, H., and Isnarto, M., "Effectiveness of Problem Based Blended Learning (PB2L)Model with Blended Learning on Improving Creative Thinking Ability in Mathematical Problem Solving," International Conference on Science and Education and Technology 2018 (ISET 2018). Atlantis Press, 2018.

[21] Boelens, Heij, "The development of semantic blocking in children," British Journal of Development Psychology, vol. 35, no. 2, pp. 310-315, 2017

[22] Soh, K., "Fostering student creativity through teacher behaviors," Thinking Skills and Creativity, vol. 23, pp. 58-66, 2017.

[23] Richardson, C and Mishra, P., "Learning environments that support student creativity: Developing the SCALE," Thinking Skills and Creativity, vol. 27, pp. 45-54, 2017. 
[24] Tsai, C.Y., Horng, JS, Liu, CH, Hu, DC, Chung YC., "Awakening student creativity: Empirical evidence in a learning environment context," Journal of Hospitality, Leisure, Sport \& Tourism Education, vol. 17, pp. 28-38, 2015.

[25] Wahyudi, W. and Winanto, A., "Development of Project-based Blended Learning (PjB2L) Model To Increase PreService Primary Teacher Creativity," Journal of Educational Science and Technology (EST), vol. 4, no. 2, pp. 91-102, 2018.

\section{BIOGRAPHIES OF AUTHORS}
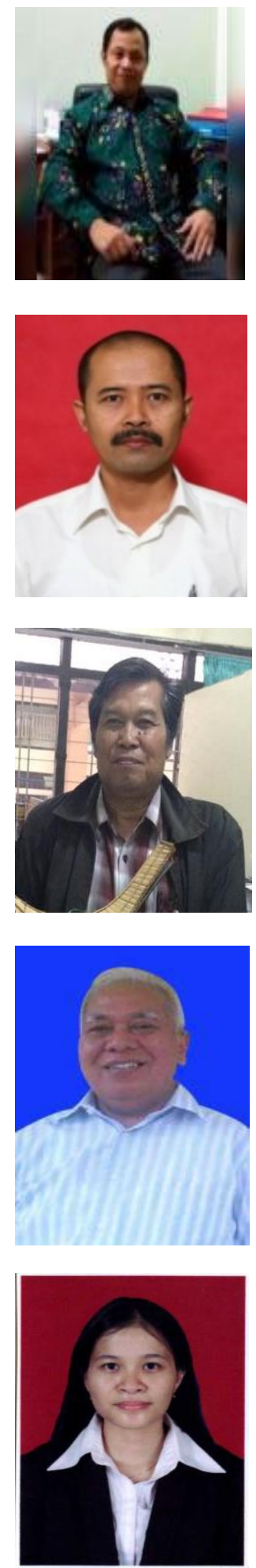

Wahyudi, born in Purwodadi, Grobogan, 2 February 1981. Taught at Universitas Kristen Satya Wacana in Salatiga since 2006. In 2009, he completed a postgraduate program in the field of Mathematics Basic Education at UNY, Yogyakarta. In 2016 he took Mathematics Education Program (S3) at UNNES Postgraduate Semarang. Active in research and service in internal grants and tertiary grants, national and international cooperation. Some of the books that have been written include the 2013 Pengembangan Pembelajaran Matematika (Widyasari Press Publisher, Salatiga, with TEAM), 2017 Program Pengalaman Lapangan (PPL), (Tisara Grafika Publisher, Salatiga, TIM), 2017 Strategi Pemecahan Masalah Matematika, (Publisher Tisara Grafika, Salatiga, with TEAM), and Problem-based Learning dalam Pembelajaran Matematika 2018 (Tisara Grafika Publisher, Salatiga).

St. Budi Waluya born in Magelang, 7 September 1968. Professor in the field of mathematics education at Universitas Negeri Semarang. His doctoral education in the Aplied Mathetmatic field was completed at Delft University Of Technology, Netherlands. S2 and S1 education are each completed at Bandung Institute of Technology (ITB) and Semarang State University. His dissertation entitled integral equations On Asymptotic Approximations of First Integrals for a Class of Nonlinear Oscillators printed Optima Grasche Communicatie Rotterdam. Active in the field of research and community service both internally, nationally and internationally.

Hardi Suyitno born in Magelang, 7 September 1968. Professor in the field of mathematics education at Universitas Negeri Semarang. His doctoral Philosophy of Mathematics was completed at Gadjah Mada University, Yogyakarta. S2 and S1 education are each completed at Malang State University and Yogyakarta State University. Some of the books that have been written include the 2013Filsafat Matematika, 2010 Linear Programing, 1997 Linear Programing.

Sutriyono born in the District of Semarang on September 1, 1953. Professor in the field of mathematics education at Universitas Kristen Satya Wacana in Salatiga. S1 mathematics education from Sanata Dharma University Yogyakarta, S2 State University of New York and S3 from the University of Malaya. Active in the field of research and community service both internally, nationally and internationally. Active in assessing the credibility of Kopertis Lecturer Functional region VI Central Java.

Indri Anugraheni, born in Yogyakarta, 11 June 1983. Teaching history, in 2012 teaching at Sanata Dharma University, 2013 - 2016 at Atmajaya Indonesian Catholic University Jakarta, 2016 - now teaching at Universitas Kristen Satya Wacana in Salatiga. In 2006 she obtained a Bachelor's degree in Mathematics Education at Sanata Dharma University. In 2012, she completed the postgraduate (S2) study program in Basic Education Concentration in Mathematics at State University of Yogyakarta (UNY). 